International Journal of Agriculture, Environment and Bioresearch

Vol. 06, No. 03; 2021

ISSN: $2456-8643$

\title{
PROBLEM OF PACIFIC COHABITATION BETWEEN THE LOCAL POPULATION AND NATURAL RESERVES: CASE OF THE MONT HOYO NATURE RESERVE
}

\author{
AMSINI MUTUZA Fidèle \\ Assistant of the Higher Pedagogical Institute of LUBUTU (ISP LUBUTU), Department of Geography and \\ Environmental Management (GGE). Lubutu Territory, Maniema Province, DR Congo \\ https://doi.org/10.35410/IJAEB.2021.5636
}

\begin{abstract}
The study on peaceful problem of coexistence between the local communities and natural reserves: the case of Mount Hoyo natural reserve spans the period from 2008 to 2016.

On investigation ground conducted 150 respondents, including 26 agents of the ICCN has led us to the following results: The factors conducting to non-peaceful coexistence and conflicts between local people and the mount Hoyo natural reserve, are banning all exploitation activities in the reserve (100\%), the change of management method (90\%); they are followed by the nonrecruitment of indigenous staff in the ICCN (67.3\%), ignorance of the true limits of the reserve by the local folk $(67.3 \%)$, rejection by the population of the documents creating the MHNR $(66.6 \%)$ and non-consideration of by ICCN, the Congolese park authority of specific demands of the neighboring population $(66 . \%)$

Against, the consequences of these conflicts are manifested by the kidnapping of park rangers by local militias in collaboration with the local population $(76.6 \%)$, the refusal of the population to work with ICCN (68\%), which promotes luck of interest of the local population in the activities of the ICCN (66.6\%) and the unregulated exploitation of the MHNR resources by the local population $(59.3 \%)$.

- Solving strategies conflicts related to this non-peaceful coexistence between the MHNR and local people are in the actions to be achieved by the ICCN, the actions to be realized by the local population and the actions to be undertaken by the partners of ICCN.

- Although the creation of the nature reserve of Mount Hoyo was not only the basis for conflicts with local communities, it has also had a positive impact on the development of the environment by the establishment of a micro development (CBNRM) (100\%), the recovery of tourism (76.6\%), the arrival of partners to support ICCN activities and the local population (74.6\%) and recovery security $(66.6 \%)$.
\end{abstract}

Keywords: Peaceful Coexistence, ICCN, Local Population and Nature Reserve of Mont Hoyo.

\section{INTRODUCTION}

Currently, it is agreed that all national parks as well as nature reserves are facing major challenges in terms of poaching, mining or forestry, on the one hand and that of peaceful cohabitation between the surrounding population accusing a high growth rate and protected areas 
Vol. 06, No. 03; 2021

ISSN: $2456-8643$

on the other hand. Thus, we start from an observation observed of negotiations or arm wrestling between the managers of protected areas and this surrounding population seeking means of subsistence: arable land for agriculture, logging and mining concessions but also meat. Bush which provides the main animal protein resources for consumption which it supposes to be illegally deprived of by the presence of the Congolese Institute for the Conservation of Nature (ICCN).

This difficult cohabitation is perceived as a constraint that each party has to circumvent to protect its inalienable interests. On the one hand, the local population of WalesseVonkutu, feel that the redeployment since 2008 by the ICCN of the Park Guards at Mount Hoyo is a clear and definite way of preventing them from accessing natural resources apart from the substitutes they had in their region and on which they based their main sources of income and their living conditions. On the other hand, the sovereign mission of ICCN is to conserve nature in the DRC in general, and particularly that of the RNMH in this specific case.

Faced with this open and sometimes recurring confrontation, the need to identify possible solutions is imperative, among other things, the creation of local structures that can reduce or lead the camps to smooth out the angles, to facilitate peaceful cohabitation between this local populations of the Nature Reserve of Mount HOYO (RNMH) to lead to a sustainable conservation of this reserve. It is from this perspective that COCO (community conservation) was born, which is a conservation approach for the local population and with the local population. This concept can also be defined as participatory conservation integrated with community development (Katumwa, 2016).

This work aims to develop ways and means that can allow peaceful cohabitation between the local population and the RNMH through conservation-development actions; that is to say, those which take into account the real needs of the populations and the consensus on the management of natural resources around this heritage which is the Mont Hoyo Nature Reserve.

It is in this perspective and in order to allow concerted management, we have assigned ourselves the mission of identifying the ways and means leading to peaceful cohabitation between the surrounding population and the RNMH, while ensuring good management of the reserve while meeting the need to meet the needs of the surrounding population.

In view of the foregoing, our issue revolves around the following question: how can we establish good so-called inclusive management capable of ensuring peaceful coexistence between the managers of the RNMH and the local riparian population.

Also, however, the concern remains. Will the hope placed in the new approach to community conservation meet the expectations they arouse in WalesseVonkutu communities, provided that the recurring conflicts documented bear witness to visible manifestations which highlight the difficult links between guaranteed institutional issues? by ICCN and local people. Indeed, while ICCN as a public body in charge of the management of protected areas in the Democratic Republic of Congo (DRC) following Decree 10/15 of April 10, 2010 is engaged in conservation in accordance with the provisions of the Law 14/003 of 11 February 2014 relating to the conservation of nature evoking ecological reasons for the protection of endemic or endangered species, the protection of biodiversity, the preservation of landscapes to justify the sanctuary of the nature reserve, while that the local communities, in particular the WalesseVonkutu - consider legitimate and undeniable the use of the resources available in these areas then disputed, yet an 
Vol. 06, No. 03; 2021

ISSN: $2456-8643$

integral part of their territories. Hence the relevance of the question, how to reconcile the use of natural resources and protection of the environments constituting the RNMH?

To this concern, the resolution of conflicts related to this non-peaceful cohabitation between the RNMH and the local population will find root in the National Strategy for Community Conservation in protected areas (ICCN, 2015), reflecting in particular the strategic importance of issues related to the involvement of riparian and indigenous populations in maintaining the integrity of protected areas, by enhancing the environmental services provided by protected areas for the benefit of these same actors, and by promoting conservation-development activities with the aim of contribute to their well-being.

The systemic method which will consist in "managing well the protagonists of two forces present in an environment of Mont Hoyo, that is to say managing its future, and managing its future is to manage the non-conflictual cohabitation between the managers and the community. riparian population. To do this, a matrix will retrace the questions and their assumptions, variables, indicators, sources, data collection techniques as to this.

The period covered by this study goes from 2008 to 2016. The choice of the starting year is justified by the fact that it constitutes the resurgence of a new deployment of the Park Wardens at Mont Hoyo after 12 years of absence in these areas, and this following the throes of the so-called repetitive wars of liberation, from 1996 to 2008, while the year of the end is due to the fact that it is the period during which the Department of Community Conservation had sufficiently benefited from substantial support for the operationalization on a area of the RNMH, in Irumu Territory, Ituri Province, eastern DRC.

This theme does not seem to be the first in the world of nature conservation in the DRC. As much as it aligns itself with a series of other previous researchers who have already approached this subject in one way or another, particularly those listed below, it is as original as it is situated at the hinge between two legal tools, in particular Ordinance-Law 69-041 of August 22, 1969, the execution of which proved difficult, due to the lack of being able to adapt to the new challenges imposed by the fight against poverty of the neighboring populations who do not actively participate in the management of protected areas in order to derive benefits and legitimate benefits (Official Journal of the DRC. Law 14/003 of 1 February 2014 relating to nature conservation. Official Journal, Special issue, 55th year and the new law 14/003 which it is part of the will expressed by Article 202, point 36, paragraph $\mathrm{f}$, of the Constitution and incorporates the provisions of Articles 203 and 204 relating to the competences recognized to the Central Power and to the Province with an emphasis on the participation of local communities in the process of 'development and implementation of the national policy for the conservation of biological diversity.

Paul VIKANZA KATEMBO, Protected Areas, Space and Development in Northeastern DR Congo. Thesis presented with a view to obtaining the degree of doctor in political and social sciences, 2011. UCL Presses Universitaires de Louvain In this study, the author concludes that in the Mayangose zone, the recurrent conflicts of the boundaries of the PNVi (Parc National Virunga) imply a general climate of scarcity of arable and fertile land. The repeated seizures and retakes of the strips of land disputed between the populations and the structures for the protection 
of the park, the repetitive clashes and violence between these antagonists and the media coverage that accompanied these quarrels, are the main elements that have brought the public place to the difficult links between conservationists and local populations. The difficult and unfinished process of clarifying the boundaries of the $\mathrm{PNVi}$, the inconclusive results of the joint commission for clarifying and demarcating the boundaries of the PNVi and the lasting reciprocal mistrust between the protagonists are characteristic elements which prove the limits in the current management of the PNVi. PA conflicts in the region.

NASIBU TCHETCHE NASSOR, Diagnosis and Perspectives on Mining in the face of COCOPA within the RFO, 2012. The Researcher shows here that, in the different provinces of the DR Congo with different realities, one notices here and there populations who have lost their land to the profit sometimes of forestry or mining industries sometimes of protected areas. Abandoned to their sad fate, these populations no longer know what the devil to indulge in except to be the workforce paid in monkey money in these companies and institutions. To be honest, mining squares as much as protected areas and forest blocks put peaceful populations in prison. Consequently and to speak only of protected areas, the problem of parks and reserves raises an opposition of interest between the State and the local populations to the point of being a condiment of recurring conflicts: This is the case of the provinces of North and South Kivu as well as Orientale province.

Joseph KAMBALE MUKIRANIA, Anarchic exploitation of the Virunga National Park. Causes and consequences. Case of "Mayangose" (2000 - 2001), 2002. Here the author shows us the causes which pushed the population to the massive destruction of the Park, taking into account the insufficiency of knowledge observed among the population in relation to the importance of nature for man and the consequences that await him following its destruction. To face these problems, he proposes a project aiming to involve the population in the management of the Park while meeting their needs for survival through activities initiated around this heritage.

In the light of all these works, we note that as much as we have Protected Areas, as much we have conflicts. Thus, it appears that conflicts exist almost around all our protected areas; they are either multifaceted or multidimensional. The main question that then arises is how to eradicate these conflicts for the benefit of a sound management of our protected areas while taking into account the well-being of the surrounding population.

\section{STATEMENT OF FACTS SUBJECT TO STUDY}

The Democratic Republic of Congo, through its network of protected areas (PA) rich in biodiversity, still covers less than $15 \%$ of the national territory and has eight national parks (Virunga, Garamba, Salonga, Maiko, Kundelungu, Upemba, Lomami and Kahuzi-Biega ) and more than 57 nature and hunting reserves, covering an estimated area of 22 million hectares. The global importance of many of these sites has been recognized and made the DRC an indisputable great environmental power, both on the African continent and on the planet. (Shamavu et al, 2015) 
However, all these protected areas are confronted with the problem of peaceful cohabitation with the riparian population which continues to increase very quickly, suddenly; it needs vast areas of arable land for agriculture and for the satisfaction of his basic needs. Consequently, a duality is created because on the one hand the population needs spaces for their activities, while on the other, these spaces are jealously managed by ICCN within the framework of nature conservation. (Plumptre et al, 2015)

The local population always assumes that the establishment of a PA in their region is synonymous with the confiscation of their lands, heritage bequeathed by their ancestors of which they have full rights of use. This is why, for the majority of the population living in the vicinity of the PAs, the presence of Gardes Parc means the prohibition of hunting, the stopping of forestry and mining operations within their land inherited from ancestors. This design does not leave the PAs without negative impacts and torpedo conservation activities and even, renders ineffective the efforts of the ICCN to ensure the control of the physical integrity of the natural space put to its management within the framework of the protection of Natural Resources. On the other hand, ICCN plays the role of conserving biological diversity, it is undeniable in order to perpetuate the biological resources essential for the sustainable socio-economic development of the Democratic Republic of the Congo, the socio-economic systems, formal and informal existing in the country, seem to put in duality the urgency of conserving biological resources with the imperative necessity of survival of the populations and of development.

Unfortunately, it should be noted that apart from the new approach to community conservation which greatly opens its door for discussions of all kinds before the creation of a PA in a region and thus promote the consideration of various demands for the local population, all the PAs do not allow a general improvement in the living conditions of a good number of people living in the surroundings because they were created, in most cases, during the colonial era on the basis of the approach known as police conservation where the population was neither consulted nor involved either in the creation or in the management of a PA. Moreover, she was not informed in advance of the benefits she could derive from nature conservation.

The RNMH is no exception to this sad reality. It is experiencing serious problems in terms of cohabitation with the local population, which thus prevents its good management. This is why, in order to allow concerted management by reducing the conflict between managers and the local population, we strive to identify the ways and means that can be implemented for peaceful coexistence between the surrounding population and the RNMH, while ensuring good management of the reserve to meet the needs of the surrounding population.

\subsection{Brief presentation of the Chiefdom of WalesseVonkutu}

The chiefdom of WalesseVonkutu is located entirely in the Territory of Irumu, Ituri Province in the northeast of the DRC. This chiefdom is located south of Irumu and forms its boundary with the Province of North Kivu. Its capital Ofay and extends from west to east, on a strip located between $29^{\circ} 5^{\prime}$ and $30^{\circ} 2$ 'east longitude, over a space between $0^{\circ} 13^{\prime}$ and $01^{\circ} 8$ 'north latitude. This Chiefdom covers an area of $786.76 \mathrm{~km} 2$ (Civil Status Office of the Territory of Irumu, 2008). 
Administratively, it is subdivided into five groupings, namely the Bandavilemba, Bokutso, Bandiangu, Bundingili and Bakpulu groupings.

\subsubsection{Demographic Aspect}

In the following table, we will present the demographic situation of the Collectivity-Chiefdom of WalesseVonkutu according to groupings, age and sex.

Table 1: Statistics of the population of the collectivity-Chiefdom of WalesseVonkutu, Year 2008

\begin{tabular}{|l|c|c|c|c|c|}
\hline \multirow{2}{*}{ Groupement } & \multicolumn{2}{|l|}{} & \multicolumn{2}{l|}{} & \multirow{2}{*}{$\begin{array}{l}\text { TOTAL } \\
(*)\end{array}$} \\
\cline { 2 - 5 } & HOMMES & Mineurs & Adultes & Mineurs & \\
\hline BAKPULU & 1767 & 1224 & 1998 & 1823 & 6812 \\
\hline BANDAVILEMBA & 4135 & 6599 & 4856 & 5016 & 20606 \\
\hline BANDIANGU & 3671 & 3224 & 3797 & 3324 & 14016 \\
\hline BOKUTSO & 3834 & 3234 & 3537 & 3693 & 14298 \\
\hline BUNDINGILI & 2107 & 2006 & 2215 & 2437 & 8765 \\
\hline TOTAL & $\mathbf{1 5 5 1 4}$ & $\mathbf{1 6 2 8 7}$ & $\mathbf{1 6 4 0 3}$ & $\mathbf{1 6 2 9 3}$ & $\mathbf{6 4 4 9 7}$ \\
\hline
\end{tabular}

Source: Civil Status Office of the Community-Chiefdom of WalesseVonkutu, 2008.

* It is imperative to point out that the Pygmy peoples are not included in these statistics.

Table 2: Statistics of the population of the community-Chiefdom of WalesseVonkutu, Year 2016

\begin{tabular}{|c|c|c|c|c|c|}
\hline \multirow[t]{2}{*}{ Group } & \multicolumn{2}{|l|}{ MEN } & \multicolumn{2}{|c|}{ WOMEN } & \multirow[t]{2}{*}{ TOTAL $(*)$} \\
\hline & Adults & Minors & Adults & Minors & \\
\hline BAKPULU & 11374 & 13388 & 15797 & 15624 & 56183 \\
\hline BANDAVILEMBA & 15338 & 17471 & 20600 & 22222 & 75631 \\
\hline BANDIANGU & 6714 & 7032 & 8242 & 8297 & 30285 \\
\hline BOKUTSO & 6834 & 7834 & 7537 & 8693 & 30898 \\
\hline BUNDINGILI & 6820 & 6129 & 8430 & 7390 & 28769 \\
\hline TOTAL & 47080 & 51854 & 60606 & 62226 & 221766 \\
\hline
\end{tabular}

Source: Civil Status Office of the Community-Chiefdom of WalesseVonkutu. 2016 .. (*) It is imperative to point out that the Pygmy peoples are not included in these statistics.

\subsubsection{Brief overview of the Mont Hoyo Nature Reserve}

\subsubsection{Geographic location}

With an estimated area of $316 \mathrm{~km} 2$, the Mont Hoyofut Nature Reserve created by Secretary General's Ordinance No. 74 / Agri. Of February 28, 1947, amended by Ordinance No. 318 / 
Agri. of October 14, 1947 and extends over $29^{\circ} 12$ 'and $29^{\circ} 15^{\prime}$ ' east longitude and $01^{\circ} 1$ ' and $01^{\circ} 5^{\prime} \mathrm{E}$, north attitude (Fig. 1 below). It is located in the territory of Irumu in Ituri Province in eastern DRC. It straddles two communities, a good part of which is circumscribed in the communities of WaleseVonkutu and a small portion in that of the Walendu Bindi.

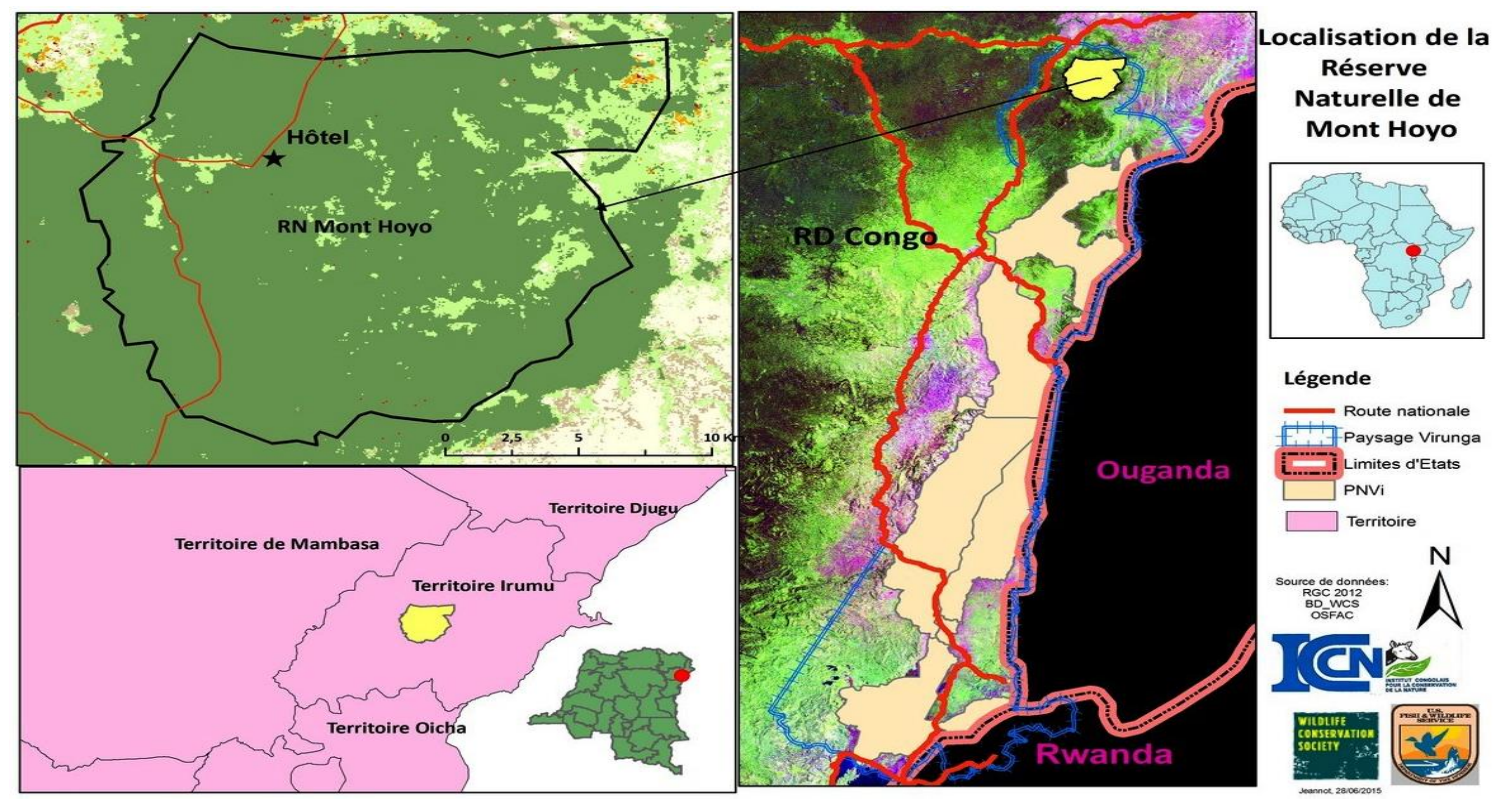

Figure 1: Location of the Mont Hoyo Nature Reserve in relation to the DRC and in the Virunga landscape

This reserve is dominated by a huge forest that begins about twenty kilometers west of Irumu; it is almost uninhabited (if only along the roads), in the triangle formed by the three road lanes Komanda-Beni, Komanda-Bunia and Bunia - Beni via Boga and Idohu. Very dense, with its majestic foliage, it has remained almost intact in this triangle. Huge trees can be seen there reaching up to $40 \mathrm{~m}$ in height, the average being around $20 \mathrm{~m}$. There are also many stumps or remains of sawnwood from old farms from the period of the last armed rebellions.

The Mont Hoyo massif is characterized by an equatorial climate with dense forest. Its caves present a phreatic-type labyrinth network, slightly altered by a vadose-type morphology. The summit of Mount Hoyo rises to an altitude of $1450 \mathrm{~m}$.

This reserve is located between the Ituri depression (Bombuo river) to the west, the Irumu basin to the north, the Semliki valley (West African tectonic ditch) to the east and the right bank of the Loya to the north. South. (A.J. Plumptre et al, 2015.). 


\section{International Journal of Agriculture, Environment and Bioresearch}

Vol. 06, No. 03; 2021

ISSN: $2456-8643$
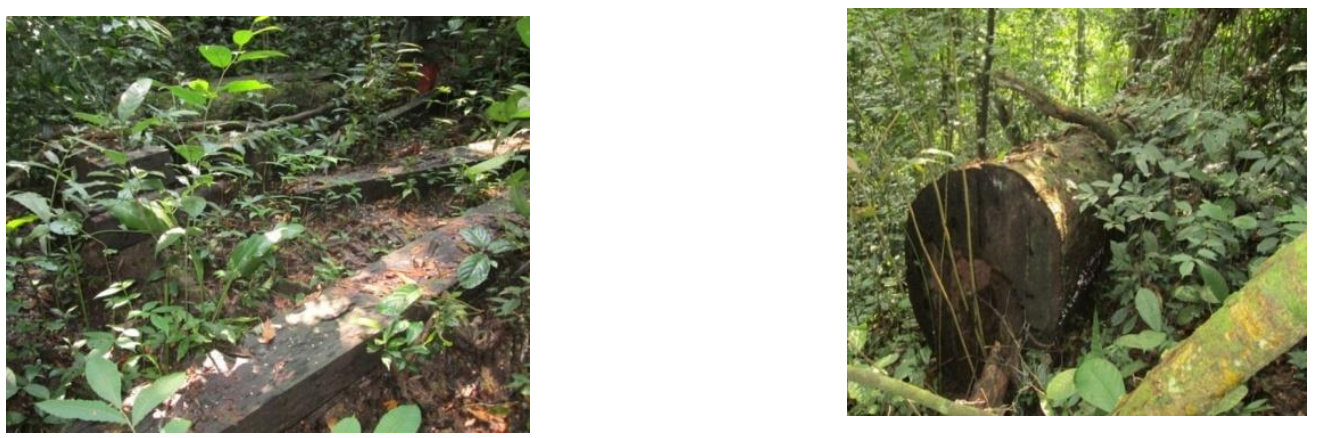

Figure 2: Logging sites abandoned following surveillance activities in the RN Mont Hoyo

This part of the national territory is among the hardest hit by the armed conflicts which plagued the country between 1994 and 2003, especially the interethnic disputes between the Hema and the Lendu (Ngiti). Apart from the loss of human life, they caused displacement of populations and destruction of socio-economic infrastructure.

Among the indigenous peoples of the Mount Hoyo region are the BalesseVonkutu and some Pygmies. These two peoples do not have an agricultural vocation, they sometimes practice hunting and gathering. In addition, to survive, they are used by other communities as labor in many activities such as in rural activities: This has meant that the forest does not face strong threats from agriculture.

It should be noted that the majority of farmers in the region are communities from North Kivu who went there in search of land. This migrant population bought land at ridiculous prices and exploited it through slash-and-burn agriculture. The main crops found in the region are maize, cassava, bananas, sweet potatoes, rice, oil palm, cocoa, beans.

Apart from agriculture, the population produces charcoal which supplies large towns and cities such as Bunia, Beni, Butembo and even Goma.

\subsection{Methodological approach}

\subsubsection{Identification of variables and their conceptualization}

\subsubsection{Identification of variables}

The variables retained in the context of this work are:

- The management mode of APs as an independent variable;

- The type of cohabitation between the population and the A Ps as a dependent variable;

- Socio-economic aspects as a control variable and

- Alternative actions or projects as an intermediate variable. 


\subsubsection{Schematization of Variables}

Figure 3: Relationship between variables

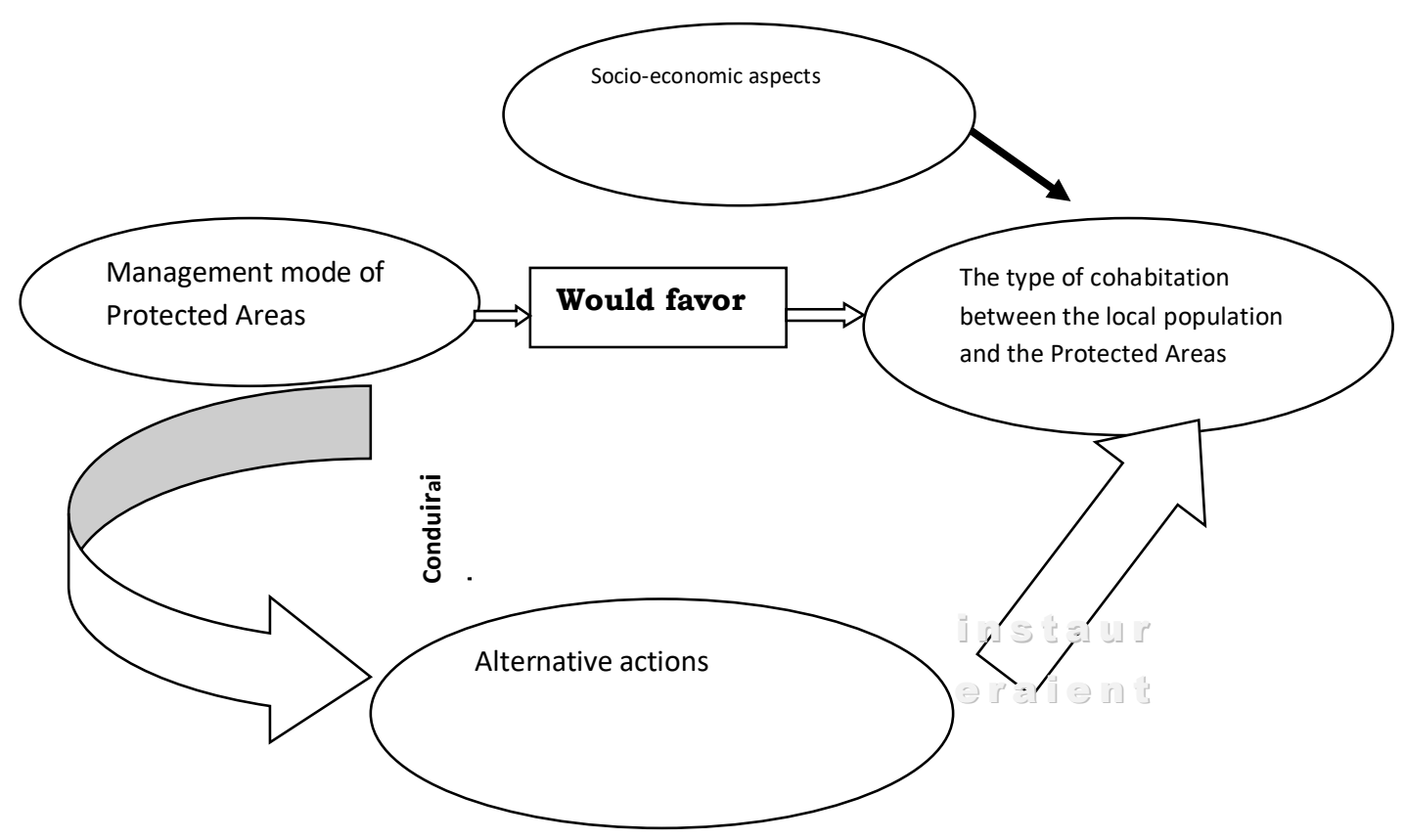

\subsubsection{Administration mode}

The survey questionnaire was administered to each respondent who was able to read and understand after a mutual presentation between the researcher and the respondent. All the statements made by the respondent were filled in on the survey forms or protocols. In total, 150 people of all categories and sexes (Farmers, Religious, Teachers, Nurses, ICCN people and other State officials) were interviewed according to the criteria below;

\subsection{Case selection criteria}

\subsubsection{Inclusion criteria}

- Be a resident of one of the groups having influence on the RNMH;

- Be available to answer us and;

- Be at least 18 years old.

\subsubsection{Exclusion criteria}

- Refusal to answer questionnaires; 
- Do not live in one of the groups having influence on the RNMH.

- Be under the age of 18.

\section{PRESENTATION AND ANALYSIS OF RESULTS}

In this chapter has two sections, the first will present the tabulated data, followed by discussions of the results.

\section{Section 1: Presentation and Analysis of Results}

We analyze the results obtained on our respondents which will be presented in tabular form followed by brief comments and discussion of these results. Given the completeness of the questionnaires, we will choose those which are more important to answer the question-problem and to allow us to achieve our objectives.

\subsubsection{Varied mono presentation of results}

In this section, the work will focus on the following different points:

- Factors favouring conflicts of peaceful cohabitation between the local population and the RNMH;

- Consequences of conflicts linked to non-peaceful cohabitation between the population and the RNMH;

- Strategy for conflict resolution of non-peaceful cohabitation between the local population and the RNMH;

- Development factors generated by the creation of the RNMH.

and Factors favouring the conflict of peaceful cohabitation between the local population and the RNMH

Under this point, we present the different factors that do not allow the good cohabitation between the local population and the Nature Reserve of Mont Hoyo.

To the question asked of our respondents whether the prohibition of all activities relating to exploitation in the Mont Hoyo Nature Reserve would create a conflict between the population and the managers of the Mont Hoyo Nature Reserve

Table 3: Explanatory factors for the non-peaceful cohabitation between the Mont Hoyo Nature Reserve and the local population, according to the latter.

\begin{tabular}{|l|l|l|}
\hline \multicolumn{1}{|c|}{ Typology of Problems } & Frequency & \multicolumn{1}{|c|}{$\%$} \\
\hline $\begin{array}{l}\text { Prohibition of all activities relating to exploitation (forestry, mining } \\
\text { and perennial agriculture) in the Mont Hoyo Nature Reserve }\end{array}$ & $150 / 150$ & 100 \\
\hline
\end{tabular}


Vol. 06, No. 03; 2021

ISSN: $2456-8643$

\begin{tabular}{|l|l|l|}
\hline Change in the way the Reserve is managed & $135 / 150$ & 90 \\
\hline Non-recruitment of natives in the ICCN / RNMH Staff & $101 / 150$ & 67,3 \\
\hline $\begin{array}{l}\text { Lack of knowledge of the real limits of the Reserve by the local } \\
\text { population }\end{array}$ & $101 / 150$ & 67,3 \\
\hline $\begin{array}{l}\text { Non-compliance by ICCN with the specifications drawn up by the } \\
\text { local population }\end{array}$ & $99 / 150$ & 66 \\
\hline Rejection by the population of documents creating the RNMH & $100 / 150$ & 66,6 \\
\hline $\begin{array}{l}\text { Poor installation procedure for Park Guards in the RNMH (i.e. } \\
\text { install Park Guards without consulting the local population, without } \\
\text { the consent of the population) }\end{array}$ & $88 / 150$ & 58,6 \\
\hline $\begin{array}{l}\text { Non-acceptance by the local population of the presence of the park } \\
\text { wardens in the environment }\end{array}$ & $85 / 150$ & 56,6 \\
\hline $\begin{array}{l}\text { Lack of understanding of the purpose of nature conservation by the } \\
\text { local population }\end{array}$ & $85 / 150$ & 56,6 \\
\hline $\begin{array}{l}\text { Low involvement of the local population in the management of the } \\
\text { Mont Hoyo Nature Reserve }\end{array}$ & $78 / 150$ & 52 \\
\hline $\begin{array}{l}\text { Refusal by the population of the presence of ICCN in the } \\
\text { community }\end{array}$ & $71 / 150$ & 47,3 \\
\hline Problem linked to the galloping demographics & $66 / 150$ & 44 \\
\hline $\begin{array}{l}\text { Intoxication of the population against ICCN by some leaders } \\
\text { Disappearance of some villages that once were inside the Mont } \\
\text { Hoyo Nature Reserve }\end{array}$ & $65 / 150$ & 43,3 \\
\hline Weak involvement of the authorities at national level & 16,6 \\
\hline
\end{tabular}

Source: Our surveys, June 2016

The local population believes that the prohibition of all exploitation activities in the reserve is mainly at the base of the disagreements between the local population and the managers of the $\mathrm{RNMH}$, then comes the problem related to the change of the management mode, it is that is to say, the transformation of a tourist site into a nature reserve (90\%).

Added to this is the problem due to the non-recruitment of originals among the ICCN staff in Mont Hoyo as well as the ignorance of the real limits of the reserve (67.3\%). During the period of this study, the Mont Hoyo Nature Reserve had a staff of 26 staff, 4 of whom came from the 
Province of Ituri and the others 22 came from the province of North Kivu. Let us discover in the table below the main problems linked to the creation of the reserve in the area.

b. Consequences of conflicts linked to the non-peaceful cohabitation between the local population and the Mont Hoyo Nature Reserve

We discuss under this point the various consequences that the conflict linked to the non-peaceful cohabitation between the local population and the RNMH can have on the proper functioning of the latter.

Table 4: The main problems that make the local population against the presence of ICCN Agents (RNMH).

\begin{tabular}{|l|l|l|}
\hline Prioritization of Main Problems & Frequency & $\%$ \\
\hline Lack of original documents establishing the Reserve & $141 / 150$ & 94 \\
\hline Prohibition of all logging activities in the Reserve & $132 / 150$ & 88 \\
\hline $\begin{array}{l}\text { Change in the management method of the Tourist Site at the } \\
\text { Reserve }\end{array}$ & $132 / 150$ & 88 \\
\hline Lack of knowledge of the true limits of the RNMH & $130 / 150$ & 86,6 \\
\hline Misunderstanding between ICCN and local Chiefs & $121 / 150$ & 80,6 \\
\hline Lack of specifications between ICCN and the local population & $120 / 150$ & 80 \\
\hline $\begin{array}{l}\text { Low involvement of the local community in the management of } \\
\text { the Mont Hoyo Nature Reserve. }\end{array}$ & $110 / 150$ & 73,3 \\
\hline $\begin{array}{l}\text { Refusal by the population of the presence of ICCN in their } \\
\text { community }\end{array}$ & $81 / 150$ & 54 \\
\hline $\begin{array}{l}\text { Weak support from the General Directorate of ICCN in resolving } \\
\text { the various problems raised }\end{array}$ & $53 / 150$ & 35,3 \\
\hline
\end{tabular}

Source: Our surveys, June 2016

By the way, the Mont Hoyo Nature Reserve was created by the colonial administration in 1947. But the original documents relating to this creation seem to be faulty and untraceable. Thus, the current Provincial Government of Ituri had drafted an order dated August 10, 2018 on the basis of the information found on the colonial decree (see Annexes) as the legal text governing the Reserve. However, the population contests this decree of the Provincial Government and alone demands the Ordinance of the colonial era. 
Table 5: Attitude of the population towards the managers of the RNMH

\begin{tabular}{|l|l|l|}
\hline Attitudes & Workforce & $\%$ \\
\hline $\begin{array}{l}\text { Kidnapping of the park rangers by the militiamen in collusion with the local } \\
\text { population (2 guards kidnapped in 2013 and 7 others kidnapped in 2015) }\end{array}$ & $115 / 150$ & 76,6 \\
\hline Refusal by the population to collaborate with ICCN & $102 / 150$ & 68 \\
\hline Disinterest of the population in ICCN activities & $100 / 150$ & 66,6 \\
\hline Anarchic exploitation of the RNMH by the population & $89 / 150$ & 59,3 \\
\hline Threats to ICCN Agents by the local population & $83 / 150$ & 55,3 \\
\hline Poaching & $71 / 150$ & 47,3 \\
\hline Popular justice & $70 / 150$ & 46,6 \\
\hline False accusations against the Park Wardens by the population & $62 / 150$ & 41,3 \\
\hline Harassment of customary chiefs to ICCN agents & $36 / 150$ & 24 \\
\hline
\end{tabular}

Source: Our surveys, June 2016

Vis-a-vis the managers of the RNMH, the population estimates that the kidnapping (kidnappings) of the eco-guards is the major consequence of the disagreements between the local population and the ICCN (76.6\%). It is imperative to point out that the 9 guards in total kidnapped had been released, either after negotiations with the customary chiefs (2013), or after the attack or the strike by the regular army (2015). Nevertheless, 3 of these 9 kidnapped guards had died a few months after their release following the tortures and shocks accumulated during detention. Those in 2013 had spent 1 month in detention and those in 2015 had spent 3 months in detention. However, $68 \%$ say they flatly refuse to collaborate with ICCN; $66.6 \%$ show complete disinterest in ICCN activities; 59.3\% proceed to the anarchic exploitation of the reserve and $55.3 \%$ make threats against the Agents of the ICCN.

Faced with this situation, in the lines that follow, we identify some strategies to be implemented to resolve the problems that arise.

C. Strategy for resolving conflicts linked to non-peaceful cohabitation between the RNMH and the local population

We analyze in this point the different actions which must be carried out to try to solve the problem which handicaps the peaceful cohabitation between the local population and the Nature Reserve of Mont Hoyo.

Table 6: Actions to be taken by ICCN to resolve the problem

\begin{tabular}{|l|c|c|}
\hline Actions to be taken & Workforce & \% \\
\hline Find the original documents establishing the RNMH & $138 / 150$ & 92 \\
\hline $\begin{array}{l}\text { Organize dialogues on a permanent basis with the local } \\
\text { population in order to ease the crisis }\end{array}$ & $131 / 150$ & 87,3 \\
\hline Raise public awareness of the importance of conservation & $112 / 150$ & 74,6 \\
\hline
\end{tabular}


Vol. 06, No. 03; 2021

ISSN: $2456-8643$

\begin{tabular}{|l|c|c|}
\hline Discuss with the population on specifications to be respected & $111 / 150$ & 74 \\
\hline Recruit the natives within the staff of the ICCN RNMH & $109 / 150$ & 72,6 \\
\hline Materialize, in a participatory manner, the limits of the RNMH & $104 / 150$ & 69,3 \\
\hline $\begin{array}{l}\text { Involve the customary authorities in the management of the } \\
\text { RNMH }\end{array}$ & $61 / 150$ & 40,6 \\
\hline Repairing the damage caused to customary chiefs & $51 / 150$ & 34 \\
\hline Train Judicial Police Officers (OPG) & $30 / 150$ & 20 \\
\hline $\begin{array}{l}\text { Initiate the creation of community forests all around the RNMH } \\
\text { (outside the RNMH) }\end{array}$ & $21 / 150$ & 14 \\
\hline
\end{tabular}

Source: Our surveys, June 2016

To mitigate the conflict, ICCN must first exhibit the original documents establishing the RNMH; then, he must organize permanent dialogues with the local population $(87.3 \%)$, sensitize the community on the importance of conservation $(74.6 \%)$, sign a specification with the community and in respect the clauses (74\%). Other points are clearly defined in the table presented above.

d. Development factors generated by the creation of the RNMH

We identify at this point some development factors generated in the community following the creation of the RNMH.

Table 7: Development factors generated by the creation of the RNMH

\begin{tabular}{|l|c|c|}
\hline Development factors & Workforce & \% \\
\hline Establishment of development micro-projects (CBNRM) & $150 / 150$ & 100 \\
\hline Resumption of Tourism & $115 / 150$ & 76,6 \\
\hline Partner arrivals & $112 / 150$ & 74,6 \\
\hline Security restoration & $100 / 150$ & 66,6 \\
\hline Support in environmental education & $92 / 150$ & 61,3 \\
\hline $\begin{array}{l}\text { Establishment of relations in favor of the RNMH at national and } \\
\text { international level }\end{array}$ & $83 / 150$ & 55,3 \\
\hline Construction of a primary and secondary school & $81 / 150$ & 54 \\
\hline Construction of a Health Center & $81 / 150$ & 54 \\
\hline Introduction of "improved stoves" & $77 / 150$ & 50 \\
\hline Rehabilitation of the Pinzili - Sokotano Road & $75 / 150$ & 50 \\
\hline Introduction of cocoa cultivation in the medium & $60 / 150$ & 40 \\
\hline Restoring forests invaded by loggers & $52 / 150$ & 34,6 \\
\hline
\end{tabular}

Source: our surveys June 2016

Analysis of this table shows that all of our respondents (100\%) confirm that the creation of the RNMH encouraged the establishment of a development micro-project such as Community-based Natural Resources Management (CBNRM). Moreover, 76.6\% speak of the resumption of tourism while $74.6 \%$ report the arrival of partners in support of ICCN activities as well as to the local population and $66.6 \%$ appreciate the reestablishment of the security acquired following the presence of the ICCN through the eco-guards.

\section{Discussion of the results}


In this section, we discuss the results of our survey around the following points:

- Factors favouring conflicts of non-peaceful cohabitation between the local population and the RNMH;

- The consequences of conflicts of non-peaceful cohabitation between the population and the RNMH;

- Conflict resolution strategies for non-peaceful cohabitation between the local population and the RNMH;

- Development factors generated by the creation of the RNMH.

\subsubsection{Factors favouring conflicts of non-peaceful cohabitation between the local population and the RNMH}

Based on analyzes of the data collected in the field, in Table 3, we found that all our respondents (100\%) confirm that the prohibition of all logging activities in the reserve is the basis of disagreements between the population local and managers of the Mont Hoyo nature reserve; Then comes the problem linked to the change in management mode, that is to say, the transformation of a tourist site into a nature reserve (90\%).

It is obvious that the biggest problem that arises is that linked to the prohibition of access or all exploitation activities in the reserve. This is why KATEMBO (2011 p 79) considers that beyond the theoretical aspects, the question which arises is that of the management of natural resources which are anchored in the most immediate reality. Most often, the many conflicts perceived as political and religious, in fact, have their roots in conflicts of access or use of resources.

Added to this is the problem due to the low recruitment of native people among ICCN staff in Mont Hoyo (only 4 agents out of a total of 26 agents are from the Province of Ituri) as well as the ignorance of the real limits of the reserve (67.3\%). In addition, Table 4 tells us that the major problem is rather that of the absence of original documents establishing the reserve in the area (94\%). Added to this is the problem due to the prohibition of all exploitation activities in the reserve (88\%) and the change in management mode to $88 \%$ without neglecting, of course, those linked to the ignorance of the real limits of the reserve (86.6\%), misunderstanding between ICCN and the local population (86.6\%), non-compliance with the specifications of the local population by the ICCN (80\%), etc. According to our surveys, a specification was initiated in 2013 by the local community. The clauses in this said notebook were exorbitant. Let us point out for example, the purchase of a $4 \times 4$ jeep to all the Chiefs of the villages (around 60 villages), the purchase of a Yamaha AG 100 motorcycle to all the Pygmy Chiefs. (Around 40 Pygmy Chiefs). While ICCN through its partners expected community support such as the construction of a school or a health center. All the attempts at negotiations to revise these specifications downwards were unsuccessful. Thus, these specifications remained a dead letter, without followup.

This corroborates well with the idea of HAMMILL AND CRAWFORD, (2009) which states that interventions such as the creation of PAs or buffer zones aim to control and in general limit the 
access of communities to important livelihoods; protect and enhance biodiversity, given population growth and development pressures. In the absence of alternatives or appropriate compensation systems, conservation interventions can result in loss of property or income for family members (who are affected differently depending on gender, age, etc. . .) and local communities. This can contribute to social fragmentation and loss of identity, as well as to further marginalization. This can result in conflicts between communities and the conservation organization.

Table 8: Factors that hinder development following the creation of the Reserve according to the local population

\begin{tabular}{|l|l|l|}
\hline Factors that hinder development according to the population & Fréquence & $\%$ \\
\hline Disagreements between the local population and ICCN & $103 / 150$ & 68,6 \\
\hline Prohibition of all logging activities in the Reserve & $97 / 150$ & 64,6 \\
\hline Lack of transparency in the management of the RNMH & $86 / 150$ & 57,3 \\
\hline Low involvement of the population in the management of the RNMH & $85 / 150$ & 56,6 \\
\hline Lack of trust between ICCN and the local population & $78 / 150$ & 52 \\
\hline $\begin{array}{l}\text { Sale by the population of portions of the forests belonging to the } \\
\text { Reserve to non-native operators }\end{array}$ & $52 / 150$ & 34,6 \\
\hline
\end{tabular}

Source: Our surveys, June 2016

Similarly, by making a simple analysis in Table 8 , we note that $68.6 \%$ of our respondents believe that the disagreements between the ICCN and the local population are at the base of the blockage of development in the area. Then come the ban on all logging activities in the reserve $(64.6 \%)$, the lack of transparency in the management $(57.3 \%)$, the weak involvement of the local population in the management of the reserve $(56.6 \%)$. \%) etc ... And that supposes that the population which lives primarily on natural resources is deprived of what it considers inherited from the ancestors and of which it has the right to exercise all the possible activities there. On the one hand, there are populations that are increasing in numbers in the neighbouring villages, and they are looking for larger and larger spaces for their survival. But at the same time, on the side of the populations, clans of former land chiefs are fighting for the recovery of this same land occupied by the reserve. Among these chiefs, rare are those who join the cause of conservation and more often than not, their purpose is to resell these lands for exploitation. On the other hand, the agents of the technical and administrative services of the State develop a double talk and an almost paradoxical approach: it is they who theoretically advocate the conservation of nature. And at the same time, they are at the origin and do not hesitate to facilitate the decommissioning and the occupation of the portions of the forests of the reserve when these can give them the net individual benefits and most often, by procedures sinuous (VIKANZA P., 2011, p 231).

In addition, article 33 of law 11/009 of July 9, 2011, on fundamental principles relating to environmental protection, stipulates that any activity likely to harm the environment is prohibited 
Vol. 06, No. 03; 2021

ISSN: $2456-8643$

in protected areas as well as in prohibited areas. Any right granted within the limits of the areas and zones referred to in the first paragraph is null.

We believe that the population must be sufficiently sensitized to allow them to have knowledge on the merits of nature conservation but also, the laws relating to its application in the event of violation of the related prescriptions; thus, we can achieve peaceful cohabitation between the population and the created nature reserve. Obviously, there must be a compensation mechanism for any damage caused by the creation of a protected area in the environment, especially in relation to the subsistence activities that were carried out in this area and on which human lives depended closely.

\subsection{Consequences of conflicts linked to non-peaceful cohabitation between the local population and the Mont Hoyo Nature Reserve}

By analyzing the consequences of the conflicts of cohabitation between the local population living in the outskirts and in the Mont Hoyo Nature Reserve, Table 5 shows us that the ecoguards are sometimes kidnapped by the local population (kidnappings) following the conflict of cohabitation with the reserve $(76.6 \%)$. However, $68 \%$ of our respondents say they flatly refuse to collaborate with ICCN; 66.6\% show complete disinterest in ICCN activities; 59.3\% proceed to the anarchic exploitation of the reserve and 55.3\% make threats against the Agents of the ICCN.

The instability and risk that characterize conflict zones can create situations where disputes are relatively common and manageable but which become overtly hostile and violent. The grievances of local communities related to conservation activities can be reinforced and exacerbated by the existing social and economic tensions that are the cause of violent conflict. Issues such as political marginalization, growing income disparities and ethnic identity can fuel and further politicize conservation grievances thereby increasing the sense of fear and injustice among affected communities. Added to factors such as the displacement of populations and the proliferation of small arms, these grievances can escalate quickly. (HAMMILL AND CRAWFORD, 2009)

In addition to these factors, another important element is that of the absence of a policy of communication of all activities initiated by ICCN beforehand with regard to the local population which is, most often, abrupt of the decisions taken. This is what KAMBALE MATESO, quoted by NASIBU (2012), tried to raise by estimating that when Protected Areas were created, people were evacuated or generally moved to peripheral areas without awareness-raising and supervision measures for the occupation of the new lands are put in place beforehand.

The result is that the evicted and frustrated populations oppose conservation and engage in conflicts with managers, in the form of demands and pressures of all kinds having considerable impacts on biodiversity.

We think that this attitude does not only allow a good management of the reserve but, can also lead to grudges between the population and the park rangers and turn into a rebellion, beyond being a factor blocking development in the middle. This is why the most urgent solutions are 
essential in trying to dispel the misunderstandings between the local population and the managers of the reserve by, for example, building the capacity of park wardens.

It is in this context that WHITE and EDWARDS (2000) believe that, to effectively manage PAs, staff must have a good knowledge of the reasons that led to the creation of these PAs, their current status and the surrounding situation and in these protected areas; that is to say, knowing how to live with the population who live in the peripheries or inside these protected areas.

3.4 Conflict resolution strategy for non-peaceful cohabitation between the local population and the RNMH

Table 9: Actions to be taken by the population living in the vicinity of the RNMH to resolve the problem

\begin{tabular}{|l|l|l|}
\hline Actions to be taken & Frequency & \% \\
\hline Participation in the various activities initiated by ICCN & $121 / 150$ & 80,6 \\
\hline Participation in exchange meetings with l'ICCN & $117 / 150$ & 78 \\
\hline Acceptance of ICCN's presence in the community & $112 / 150$ & 74,6 \\
\hline Advocate & $98 / 150$ & 65,3 \\
\hline Respect the limits of the RNMH & $95 / 150$ & 63,3 \\
\hline $\begin{array}{l}\text { Raise awareness among members of the local community through } \\
\text { community leaders }\end{array}$ & $95 / 150$ & 63,3 \\
\hline Adopt other income-generating activities & & \\
\hline Avoid mob justice (Case of the kidnappings of the Park rangers) & $58 / 150$ & 40 \\
\hline
\end{tabular}

Source: Our surveys, June 2016

To resolve the conflict situation, it is above all necessary to involve the population in the various activities initiated by ICCN (80.6\%); and in exchange meetings (78\%) while $74.6 \%$ think in turn that 'you simply have to accept the presence of ICCN in their community.

Following the actions mentioned above, the following section will shed light on the actions that ICCN partners must take to promote peaceful coexistence.

Table 10: Solutions to be undertaken by ICCN Partners to resolve the problem

\begin{tabular}{|l|l|l|}
\hline Solutions to undertake & Frequency & $\%$ \\
\hline Get involved in development works & $148 / 150$ & 98,6 \\
\hline Financial support for ICCN / RNMH & $139 / 150$ & 92,6 \\
\hline
\end{tabular}


International Journal of Agriculture, Environment and Bioresearch

Vol. 06, No. 03; 2021

ISSN: $2456-8643$

\begin{tabular}{|l|l|l|}
\hline Ensure facilitation (mediation) between ICCN and the population & $122 / 150$ & 81,3 \\
\hline Ensure compliance with the signed specifications & $101 / 150$ & 67,3 \\
\hline Consider local needs & $66 / 150$ & 44 \\
\hline Advocate for the cause of RNMH at all levels & $57 / 150$ & 38 \\
\hline
\end{tabular}

Source: Our surveys, June 2016

Based on the data in this table, ICCN partners must first get involved in development works (98.6\%); then they must financially support the ICCN (92.6\%), play the role of facilitator or mediator between the population and the ICCN (81.3\%) and ensure compliance with the specifications signed between the two parties $(67,3 \%)$.

To dispel the misunderstanding between the local population and the managers of the Mont Hoyo Nature Reserve, 92\% of our respondents say that ICCN must first exhibit the original documents establishing the RNMH; then, organize permanent dialogues with the local population $(87.3 \%)$, sensitize the community on the importance of conservation (74.6\%) and sign a specification with the community and respect the clauses of this notebook (74\%). (Table 6)

In addition, let us say that there would still exist a document issued by the colonial administration establishing the nature reserve of Mont Hoyo which dates from 1947, but a document which seems to be defective and nowhere to be found.

On the one hand, we support the solutions proposed by the population who made up our sample because the reserve must legally exist to be accepted by all but also, awareness raising will allow an understanding of the situation likely to create a climate of peace in the area. On the other hand, the specifications are adopted only in the current system of management of so-called participatory or community protected areas. However, in the protected areas created during the colonial period, including the Mont Hoyo nature reserve, there was no signature of specifications between the managers and the local population.

Furthermore, Table 9 shows us that $80.6 \%$ of our respondents think that the attitude that the population should adopt is rather to participate in the various activities initiated by ICCN; 78\% believe that it is also necessary to participate in exchange meetings, $74.6 \%$ in turn think that it is simply necessary to accept the presence of ICCN in their community. However, to achieve this, we believe that it is necessary to reinforce this aspect of even the situation which is already acquired through the sensitization sessions to make this situation even to the refractors to thus reconcile the points of view. This must also be accompanied by some actions initiated in the field to further motivate the population to feel involved in the management of the reserve and take ownership of it. It is in this sense that the population proposes some actions in their favour in the community as shown in table 10 in proportion to $98.6 \%$ of our respondents who think that ICCN partners should get involved in the works of development ; then, they must financially support the ICCN $(92.6 \%)$, play the role of facilitator or mediator between the population and the ICCN (81.3\%) and ensure compliance with the specifications signed between the two parties ( $67.3 \%)$. 
Table 11: The expectations of the local population following the creation of the RNMH

\begin{tabular}{|l|l|l|}
\hline Expectations & Frequency & \% \\
\hline Create jobs & $150 / 150$ & 100 \\
\hline Trigger development in the middle & $138 / 150$ & 92 \\
\hline Build the infrastructure & $128 / 150$ & 85,5 \\
\hline Equitably share the income from the RNMH & $87 / 150$ & 58 \\
\hline Build the offices of the customary chiefs & $82 / 150$ & 54,6 \\
\hline Build the office of the Collectivity-Chiefdom & $71 / 150$ & 47,3 \\
\hline Build houses for customary chiefs & $67 / 150$ & 44,6 \\
\hline Cover academic fees for students & $55 / 150$ & 36,6 \\
\hline Electrify the environment & $32 / 150$ & 21,3 \\
\hline Manage the RNMH transparently & $30 / 150$ & 20 \\
\hline Demarcate the Reserve in a participatory manner & $28 / 150$ & 18,6 \\
\hline Stimulate the influx of tourists to Mont Hoyo & $20 / 150$ & 13,3 \\
\hline
\end{tabular}

Source: Our surveys, June 2016

The local population expects the presence of the RNMH to create jobs; the triggering of the development process in the community (92\%), the construction of basic infrastructure (85.3\%) and so many other benefits as listed in the table above.

In the following lines, we discuss the expectations of the population with regard to the State of the DR. Congo concerning the creation of the RNMH.

Table 12: The expectations of the population vis-à-vis the Congolese State regarding the creation of the RNMH (DG ICCN, National Assembly, Senate ...)

\begin{tabular}{|l|l|l|}
\hline Expectations & Frequency & $\%$ \\
\hline Promptly publish the decree creating the RNMH & $150 / 150$ & 100 \\
\hline Pacify the integrity of the RNMH & $131 / 150$ & 87,3 \\
\hline Define the RNMH in a correct and participatory manner & $131 / 150$ & 87,3 \\
\hline Recruit park rangers from the local community & $129 / 150$ & 86 \\
\hline Financing the RNMH at its fair value & $121 / 150$ & 80,6 \\
\hline Promote participatory conservation & $107 / 150$ & 71,3 \\
\hline Rehabilitate the RNMH & $88 / 150$ & 58,6 \\
\hline Initiate development actions & $86 / 150$ & 57,3 \\
\hline Declassify part of the RNMH for the activities of the population & $86 / 150$ & 50,6 \\
\hline
\end{tabular}


Vol. 06, No. 03; 2021

ISSN: $2456-8643$

Resolve the conflict

$61 / 150$ 40,6

Source: Our surveys, June 2016

From the government of DR Congo, the population expects a rapid publication of the decree establishing the RNMH. In addition, 87.3\% hope that with the creation of the Mont Hoyo nature reserve, there will be the complete pacification of the area covered by the RNMH as well as its surroundings, but also to proceed with its exact and participatory delimitation. .

In the following table, we will then identify the methods of integrating the local population into the management of the Mont Hoyo Nature Reserve.

Table 13: Methods of integrating the local population into the management of the Mont Hoyo Nature Reserve

\begin{tabular}{|l|l|l|}
\hline Integration methods & Frequency & \% \\
\hline Recruit Agents of ICCN RNMH within the community & $109 / 150$ & 72,6 \\
\hline Involve the local population in the various activities & $101 / 150$ & 67,3 \\
\hline Involve local community leaders in decision-making & $97 / 150$ & 64,6 \\
\hline Train a few people in the community & $82 / 150$ & 54,6 \\
\hline Involve the local population during surveillance work & $68 / 150$ & 45,3 \\
\hline Communicate regularly to the population the major decisions taken & $61 / 150$ & 40,6 \\
\hline
\end{tabular}

Sources: Our surveys, June 2016

The application of all of these possible solutions will lead to the creation of jobs (100\%), the triggering of the development process in the community (92\%), the construction of basic infrastructure (85.3\%) and so many other needs as listed in table 11 .

This meets the idea according to which, faced with the growing precariousness of these populations, in high density and whose survival depends only on agriculture, the sanctuarization of resources can only raise questions. Thus, conservation policies should not only promote actions for the physical conservation of the land, but they must also aim to improve the natural conditions favorable to the survival of local populations, adds VIKANZA (2011, p 107).

By analyzing the expectations of the population vis-à-vis the state of DR Congo, Table 12 shows us that $100 \%$ of our respondents expect a rapid publication of the decree creating the RNMH. In addition, $87.3 \%$ hope that with the creation of the Mont Hoyo nature reserve, there will be the complete pacification of the area covered by the RNMH and its surroundings, but also to proceed with its exact and participatory delimitation. .

Another important aspect, raised in $71.3 \%$, is the involvement of the local population in the management of the reserve. This concern is also generally mentioned in table 13. Considered as a sine qua non for good management of the park, the involvement of communities through 
specific and visible actions is one of the factors that can help to contain the pressure of the local populations. These actions will have to respond to the various problems in an intelligent and appropriate way because, for example, for the question of lack of land and the increase in production, the land is already all cultivated the increase in production should not take the lead form of a widening of the fields around the park or an extension but rather, of an intensification of the cultures on the same grounds by the introduction of the techniques adapted to the local realities, stipulate KUJIRAKWINJA, BASHONGA and PLUMPTRE (2008 p 47) .

The analysis of the proportion of the population having an idea of the harmful consequences of human activities on nature showed us that $78.7 \%$ of our respondents confirm that human activities have an influence on the RNMH.

In general, the anthropogenic pressure on nature becomes greater when the number of those who access it becomes larger and larger. This is why there is always a problem of peaceful cohabitation when the riparian population becomes too large. This is also what VIKANZA P. (2011, p 233) thinks, which states that the factors which threaten the integrity of reserves are demographic pressure combined with the failure of the protection apparatus.

Recognizing the consequences of anthropogenic pressure on the Mont HOYO nature reserve, $100 \%$ of our respondents felt that the creation of secondary activities and the organization of a round table between the ICCN and the local population is the best way to resolve conflicts between the 2 parties involved. Similarly, $63.3 \%$ think that it is more necessary to sensitize the local population on the importance of the Reserve; $55.3 \%$ think that it is necessary to make the customary chiefs accountable and $46.6 \%$ believe that it is necessary to create a mixed surveillance system.

Thus, from this awareness of the local population on the consequences that human activities have on nature, in general and the RNMH in particular as indicated above, we think that it is obvious to look for ways and means to capitalize on this achievement for the benefit of peaceful coexistence between the nature reserve of Mount HOYO and the local population. In addition, in article 13 of the law mentioned a little further on, it is stipulated that the government must implement cooperation policies and programs with other States and partners wishing to contribute to the protection of the environment and the sustainable management of natural resources within the framework of international conventions, treaties and agreements to which the Republic is a party.

\subsection{Development factors generated by the creation of the Mont Hoyo Nature Reserve}

The creation of the Mount HOYO Nature Reserve not only generated conflicts with local communities but also had a positive impact on the development of the area, as the population pointed out in Table 7 .

Thus, we note that all of our respondents (100\%) confirm that the creation of the RNMH favoured the establishment of a micro development project (CBNRM); Moreover, 76.6\% speak of the resumption of tourism while $74.6 \%$ report the arrival of partners in support of ICCN 
activities as well as to the local population and $66.6 \%$ appreciate the reestablishment of the security acquired, following the presence of the ICCN through the eco guards.

In short, we believe that the problem that arises is rather that of understanding the merits of the existence of a reserve in the area. At least, the creation of a PA creates many development opportunities in the area by promoting exchanges with the outside world, for example, through works of art, by improving the living conditions of the local population through the construction of various basic infrastructures (hospitals, schools, hotels, roads, etc.), monetary circulation in the area, job creation as well... (ALEMA, 2014, p 35).

\section{CONCLUSION}

Our work revolves around the issue of peaceful cohabitation between the local population and Nature Reserves: Case of the Mont Hoyo Nature Reserve.

This research started from the main question which seeks to know how we can establish a good so-called inclusive management capable of ensuring a lasting peaceful coexistence between the managers of the Mont Hoyo Nature Reserve (ICCN) and the local population.

As an answer to the question posed above, we assumed that the participation of the population in the management of the reserve, the implementation of alternative projects and the involvement of ICCN in community development projects would have an impact positive on so-called inclusive management capable of ensuring peaceful coexistence between the managers of the Mount HOYO Nature Reserve and the local population.

We used the dialectical method for more efficiency, and it was supported by analytical, statistical and descriptive approaches.

The techniques used in carrying out this work are documentation, free interview and structured interview, survey questionnaires as well as direct observation.

After analyzing the data collected from the 150 subjects, we arrived at the following conclusions:

The major causes of the conflicts related to the peaceful cohabitation between the Mont Hoyo Nature Reserve and the local population are the prohibition to carry out all exploitation activities in the reserve, the non-recruitment of the local population within the ICCN, the failure to respect the limits, the change in the management mode of the tourist site to a nature reserve and the absence of the decree creating the Mont Hoyo nature reserve.

The consequences of this conflict between managers and the local population are numerous, among others the kidnappings of ICCN agents more particularly the park wardens, disinterest in ICCN activities, the refusal of the population to collaborate with the ICCN, anarchic exploitation of the reserve, threats to ICCN agents by the local population, the poaching, mob justice, false accusations against park wardens by the local population and the relentlessness of customary chiefs against ICCN agents. 
The strategies proposed by the local population to solve these problems are the rapid presentation of the ordinance establishing the nature reserve of Mont Hoyo, the participatory delimitation of the reserve, the creation of projects to fill jobs, the recruitment of sons and local girls within ICCN, the construction of basic infrastructure, the implementation of development projects and the involvement of local populations in the management of the Mont Hoyo nature reserve.

Finally, the population recognizes that the creation of the Mont Hoyo nature reserve has encouraged, to a certain extent, the resumption of tourism, the rehabilitation of some basic infrastructures such as the road which connects the headquarters with the main road (road national no.4), the rehabilitation of the Mont Hoyo hotel and drug support for health centers.

After having analyzed the various problems which arise in our study environment, we proposed a strategy of capacity building of the local population on the management of a nature reserve. The main objective is to provide a good understanding of the management of a nature reserve to facilitate peaceful cohabitation between the managers of the Mont Hoyo Nature Reserve and the local population of the WalesseVonkutu Community-Chiefdom, surrounding this reserve.

To conclude, this research is not exhaustive, other parameters remain unresolved and need to be studied by other subsequent researchers such as the problem linked to poaching, logging, exploitation of non-forest products woody, etc.

Taking into account the above, we make the following recommendations:

1. To the politico-administrative authorities: that the government ensure the protection of the reserve which is a public good; that it recruit its agents on behalf of Mount Hoyo from among the local population; that he be involved in the implementation of community development projects and that he make available the original document establishing the RNMH. Document to be found, for example, at the Tervuren Museum in Belgium or from other Belgian services having the Environment and Nature Conservation in its attributions.

2. To the local population; that it respects the laws and texts relating to nature conservation; that it supports the managers of the reserve while being actively involved in the actions initiated by the ICCN and that it stop kidnappings of ICCN agents by favouring a peaceful climate.

\section{Acknowledgement}

Scientific work is rarely the work of one person. Thus, and for our article, we benefited from the multifaceted and multidimensional support of the following people:

To the members of the technical and administrative staff of ICCN Mont Hoyo for their legendary welcome and generosity,

To Mr. Kyassa Katambwe Paul for his supervision and scientific support,

To Professors Leonard Mubalama, Prince Kaleme and Corneille Ewango for their advice and very relevant comments.

To Mr. Jean Pierre Katumwa for his guidance and constructive comments. 
To Mr. Bahanule Bafunda family for his hospitality and

To Mr. Benjamin Wilondja for his moral comfort.

\section{REFERENCE}

\section{WORKS}

1. BUTTOUD G. and NGUINGUIRI J.C., Inclusive management of the forests of Central Africa: Moving from participation to power sharing. FAO-CIFOR: Libreville-Bogor, 2016.

2. DIEUMEGARD, P., Past naturalistic statistical software, P 32. SVT teacher, Lycée Pothier, 45044 Orléans.

3. HAMMILL, A. et al; For Conflict Sensitive Conservation. Practitioner's Manual. International Institute for Sustainable Development (IISD), 2009.

4. LAROUSSE, Maxipoche, Dictionary of the French language, 2013.

5. VIKANZA, P., Protected areas, disputed areas and development in the North-East of the DR. Congo, Faculty of Economic, Social, Political and Communication Sciences, Catholic University of Louvain, ed. Online academic 2011.

6. VAUGAN, JP. And MORROW, R.M., Manual of Epidemiology for District Health Management, Geneva, WHO, 1991.

7. WEHIONG, S., Assessment and Analysis of Partnership Experiences in Forest Management in the Congo Basin. 2005.

8. WHITE, L., EDWARDS, A. African Rainforest Conservation: Research Methods, Wildlife Conservation Society, New York. 444 pp., numerous illustrations eds 2000.

\section{END OF CYCLE WORK, END OF STUDY WORK AND COURSES}

9. ALEMA, P., Environmental management, unpublished course, UAC-Bunia 2013-2014

10. EWANGO, C. and KAMBALE A., Status and Management of Protected Areas. L1 Rural Development, Unpublished, ISDR-Beni, 2013-2014

11. KATUMWA, J., Special Environmental Matters. L2 Rural Development, unpublished, ISDR-Beni, 2015-2016.

12. MUKIRANIA, J. Anarchic exploitation of the Virunga National Park. Causes and consequences. Case of "Mayangose" (2000 - 2001), TFC Inédit, ISDR BENI, 2002.

13. NASIBU, T., Diagnosis and perspectives on mining in the face of CO.CO.PA. At his from R.F.O, TFE, unpublished, ISDR-Beni 2012

14. PALUKU, JB., Initiation à la Méthode de recherche, unpublished course, ISDR-Beni, 2016. 
Vol. 06, No. 03; 2021

ISSN: $2456-8643$

\section{MAGAZINES AND ARTICLES}

15. Official Journal of the Democratic Republic of Congo, Office of the President of the Republic: Law No. 11/009 of July 9, 2011 on fundamental principles relating to the protection of the environment. 52nd Year, Special Issue, 2011.

16. Official Journal of the Democratic Republic of Congo, Office of the President of the Republic: Law No. 14/003 of February 1, 2014 relating to nature conservation. 55th Year, Special Issue, 2014

17. KUJIRAKWINJA, D., BASHONGA, G. ET PLUMPTRE, A., Socio-economic study of the North-West zone of Virunga National Park: Lubero-Butembo-Beni region, WWF-EARPO, Nairobi, 50pp + vi 2008.

18. LOBHO, J. WalesseVonkutu Chiefdom-Collective Civil Status Office, First Quarter Report, 2008.

19. LOBHO, J. Civil Status Office of the County Authority of WalesseVonkutu, First Quarter Report, 2016.

20. PLUMPTRE A.J.; Biodiversity inventory in the Mont Hoyo Nature Reserve in Irumu Territory, Ituri Province, Democratic Republic of Congo. Unpublished Report, WCS, 2015

21. CREF Network: Prevention, Management and Resolution of forestry and organizational conflicts. Training report of NGOs members of the CREF Network, 2012.

22. SHAMAVU, P et al. 2015: Protecting the Chimpanzees of Mount Hoyo through improved Law Enforcement. Unpublished report, WCS, 5.

\section{WEBOGRAPHY}

23. (https://fr.wikipedia.com) 


\section{APPENDIX $N^{\circ} 01$ : Matrix of Strategic Orientations}

\begin{tabular}{|c|c|c|c|c|c|}
\hline $\begin{array}{l}\text { Challenges to } \\
\text { overcome }\end{array}$ & Strategies & $\begin{array}{l}\text { Strategic } \\
\text { targets }\end{array}$ & Activities & $\begin{array}{l}\text { Expected } \\
\text { results }\end{array}$ & $\begin{array}{l}\text { Objectively } \\
\text { Verifiable } \\
\text { Indicators }\end{array}$ \\
\hline $\begin{array}{l}\text { The ignorance } \\
\text { of the } \\
\text { population } \\
\text { about the } \\
\text { merits of } \\
\text { conservation }\end{array}$ & $\begin{array}{l}\text { - Sensitization of the } \\
\text { population on the merits } \\
\text { of conservation; } \\
\text { - Popularization of texts } \\
\text { and laws relating to } \\
\text { conservation. }\end{array}$ & $\begin{array}{l}\text { Show the } \\
\text { local } \\
\text { population } \\
\text { the } \\
\text { importance } \\
\text { of the nature } \\
\text { reserve and } \\
\text { make } \\
\text { available to } \\
\text { them the } \\
\text { laws and } \\
\text { texts relating } \\
\text { to nature } \\
\text { conservation. }\end{array}$ & $\begin{array}{lr}\text { - contact with } & \text { the } \\
\text { political } & \text { and } \\
\text { administrative } \\
\text { authorities, } \\
\text { - organization of } \\
\text { seminars and } \\
\text { workshops an } \\
\text { protection } \\
\text { custom, } \\
\text { - Animation of radio } \\
\text { broadcasts and } \\
\text { organization of } \\
\text { training workshops, } \\
\text { - Establishment of an } \\
\text { awareness team in } \\
\text { public places (church, } \\
\text { school, market ...) }\end{array}$ & $\begin{array}{l}\text { Peaceful } \\
\text { cohabitation } \\
\text { between } \\
\text { managers and } \\
\text { established } \\
\text { local } \\
\text { population }\end{array}$ & $\begin{array}{l}\text { The letter of } \\
\text { authorization from } \\
\text { the various local } \\
\text { authorities; } \\
\text { - } 15 \text { seminars and } \\
\text { workshops on } \\
\text { protection and } \\
\text { custom organized. } \\
\text { - } 30 \text { animated radio } \\
\text { broadcasts; } \\
\text { - listening reports; } \\
\text { - the program grid }\end{array}$ \\
\hline $\begin{array}{l}\text { Poisoning of } \\
\text { the population } \\
\text { by leaders }\end{array}$ & $\begin{array}{l}\text { - Advocacy with local } \\
\text { leaders on the merits of } \\
\text { conservation }\end{array}$ & $\begin{array}{l}\text { Make local } \\
\text { leaders } \\
\text { understand } \\
\text { the } \\
\text { importance } \\
\text { of the nature } \\
\text { reserve in } \\
\text { their } \\
\text { environment. }\end{array}$ & $\begin{array}{l}\text { - contact with local } \\
\text { leaders; } \\
\text { - organization of } \\
\text { training workshops } \\
\text { for leaders; } \\
\text { - make available texts } \\
\text { and laws relating to } \\
\text { nature conservation. }\end{array}$ & $\begin{array}{l}\text { Local leaders } \\
\text { involved in } \\
\text { raising } \\
\text { awareness } \\
\text { among the } \\
\text { local } \\
\text { population }\end{array}$ & $\begin{array}{l}-10 \text { workshops on } \\
\text { the importance of } \\
\text { the reserve } \\
\text { organized; } \\
\text { - The acceptance of } \\
\text { the Reserve by the } \\
\text { local population. }\end{array}$ \\
\hline \multirow[t]{2}{*}{$\begin{array}{l}\text { Precariousness } \\
\text { of life } \\
\text { Low capacity } \\
\text { of COCOPA }\end{array}$} & $\begin{array}{l}\text { Initiate } \\
\text { income- } \\
\text { generating } \\
\text { activities; } \\
\text { - } \\
\text { Implementation } \\
\text { of breeding } \\
\text { techniques } \\
\text { - REDD + }\end{array}$ & $\begin{array}{l}\text { Encourage } \\
\text { the local } \\
\text { population to } \\
\text { capitalize on } \\
\text { other } \\
\text { economically } \\
\text { sound } \\
\text { resources }\end{array}$ & $\begin{array}{l}\text { - creation of groups } \\
\text { of village savings and } \\
\text { credit associations } \\
\text { - installation of } \\
\text { technical workshops: } \\
\text { mechanics, sewing } \\
\text { cut; } \\
\text { - introduction of } \\
\text { industrial crops } \\
\text { (cocoa) } \\
\text { - initiate the breeding } \\
\text { of small family } \\
\text { livestock, beekeeping } \\
\text { and fish farming }\end{array}$ & $\begin{array}{l}\text { Pressure on } \\
\text { the Mont } \\
\text { Hoyo nature } \\
\text { reserve due to } \\
\text { the } \\
\text { precariousness } \\
\text { of life } \\
\text { significantly } \\
\text { reduced }\end{array}$ & $\begin{array}{l}\text {-20 WITH created; } \\
\text { - Number of } \\
\text { mechanical } \\
\text { workshops and } \\
\text { seams installed; } \\
-45 \text { fish ponds } \\
\text { installed and } 85 \% \\
\text { of the population } \\
\text { sensitized on } \\
\text { breeding and } \\
\text { beekeeping. }\end{array}$ \\
\hline & $\begin{array}{l}\text { Creation of } \\
\text { community reserve }\end{array}$ & $\begin{array}{l}\text { Reduce the } \\
\text { pressure on } \\
\text { the reserve. }\end{array}$ & $\begin{array}{l}\text { identification } \\
\text { of the } \\
\text { locations; }\end{array}$ & $\begin{array}{l}\text { Significantly } \\
\text { reduced } \\
\text { pressure from } \\
\text { human }\end{array}$ & $\begin{array}{l}-2 \\
\text { community } \\
\text { reserves } \\
\text { created; }\end{array}$ \\
\hline
\end{tabular}


International Journal of Agriculture, Environment and Bioresearch

Vol. 06, No. 03; 2021

ISSN: $2456-8643$

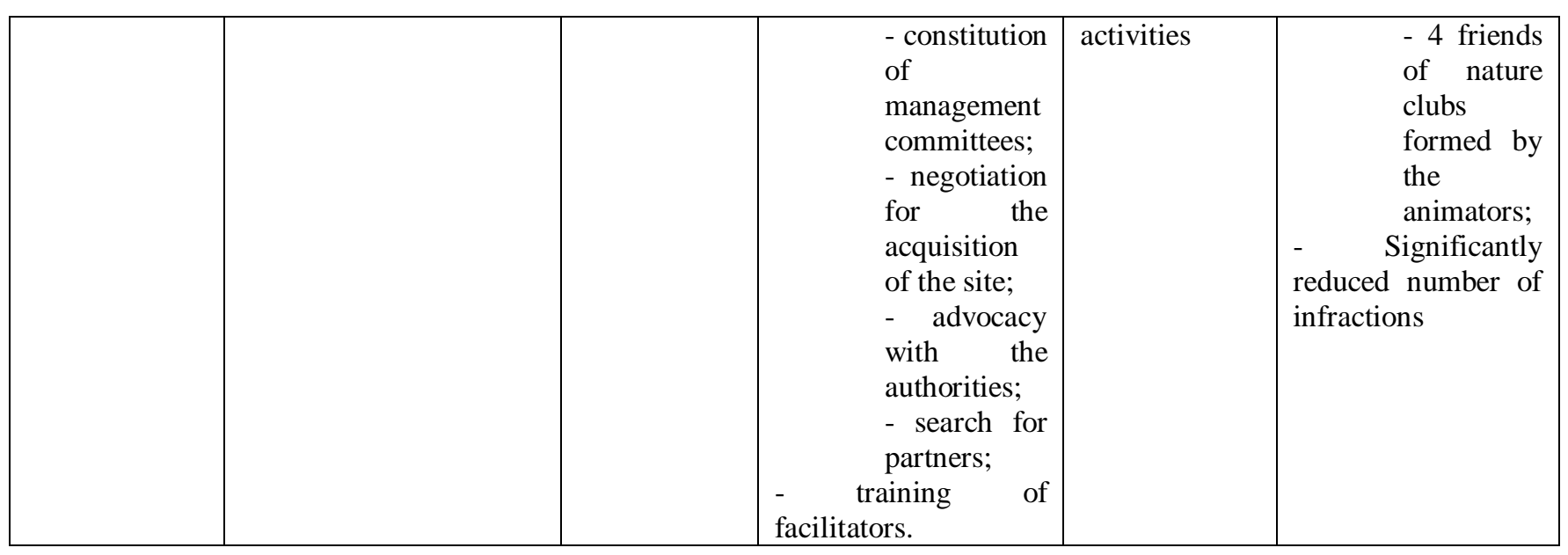

